\title{
PRIESTOROVÁ ANALÝZA DÁT Z POVRCHOVÉHO ZBERU NA LOKALITE VRÁBLE-FIDVÁR
}

\section{Dominik Drozd*}

\section{*Archeologický ústav Slovenskej akadémie vied, Akademická 2, 94921 Nitra, drozd10@uniba.sk.}

\begin{abstract}
Spatial analysis of fieldwalking data from the site of Vráble-Fidvár. The goal of this study is to introduce selected methods of spatial analysis and their contribution to evaluation of fieldwalking data. Spatial analysis encompasses various methods suitable for identification, objective evaluation and visualization of spatial patterns which are present in obtained data. This article primarily deals with sampled data, collected during a 2007 fieldwalking campaign. The dataset consisting of potsherds was spatially autocorrelated, using the global and local Moran's I coefficient, which was used to identify clusters of finds. Spatial pattern of the settlement was visualised by geostatistical interpolation method - kriging.
\end{abstract}

Keywords: spatial analysis, Early Bronze Age, fieldwalking, spatial autocorrelation, kriging

Abstrakt: Cielom tohto príspevku je predstavenie vybraných metód priestorovej analýzy a demonštrácia ich prínosu $\mathrm{k}$ spracovaniu dát $\mathrm{z}$ povrchového zberu. Priestorová analýza zahŕňa rozličné metódy umožňujúce identifikáciu, objektívne vyhodnotenie a vizualizáciu priestorovej štruktúry na základe dostupných dát. Článok sa primárne venuje vzorke z dát získaných počas povrchového zberu v roku 2007. Súbor keramických fragmentov bol podrobený analýze priestorovej autokorelácie s využitím globálneho a lokálneho Moranovho I, prostredníctvom ktorého boli identifikované najvýraznejšie zhluky nálezov. Priestorová štruktúra sídliska bola vizualizovaná pomocou geoštatistickej interpolačnej metódy kriging.

Klíčová slova: priestorová analýza, staršia doba bronzová, povrchový zber, priestorová autokorelácia, kriging

https://doi.org/10.46283/musarch.2021.1.2.03

\section{1. Úvod}

Lokalita Fidvár sa nachádza na južnom okraji mesta Vráble a patrí k najznámejším a najpodrobnejšie preskúmaným náleziskám na území Slovenska (obr. 1). V rámci početných terénnych aktivít tu bolo zachytené rozsiahle opevnené sídlisko zo staršej doby bronzovej, ktoré pokrývalo, vo svojej vrcholnej fáze, približne 11 ha vel'kú plochu. Okrem predmetného sídliska tu bolo lokalizované eneolitické a germánske osídlenie a aj dva rímske pochodové tábory (Bátora a kol. 2009; Bátora a kol. 2015; Bátora - Tóth - Rassmann 2015).

Článok sa primárne venuje problematike priestorovej analýzy a jej možnosti pri spracovaní dát z povrchového zberu z polohy Fidvár. Metódy priestorovej analýzy zatial’ nie sú v rámci slovenskej archeológie využívané v takej miere ako v zahraničí. Ich využitie úzko súvisí so základným prehl’adom v štatistike a nevyhnutnou potrebou práce s výpočtovou technikou (geografický informačný systém - GIS, programovací jazyk R).

Záujmovou oblast’ou priestorovej analýzy je priestorová štruktúra, t. j. spôsob, akým sú sledované prvky usporiadané v priestore a ich vzájomné priestorové pôsobenie (Clarke 1977, 10). Analýza priestorovej štruktúry zahŕňa súbor techník, ktoré sú závislé na lokalizácii skúmaných objektov. Dôležitým prvkom sa z tohto dôvodu stáva získavanie priestorovej informácie pomocou GPS prístrojov (Goodchild 1996, 241). Tieto metódy vo väčšine prípadov pochádzajú z iných vedných odborov, najmä geografie a geológie (Hodder - Orton 1976, 1). V kontexte predloženého článku sú rozpracované dve oblasti priestorovej analýzy: priestorová autokorelácia a kriging. 


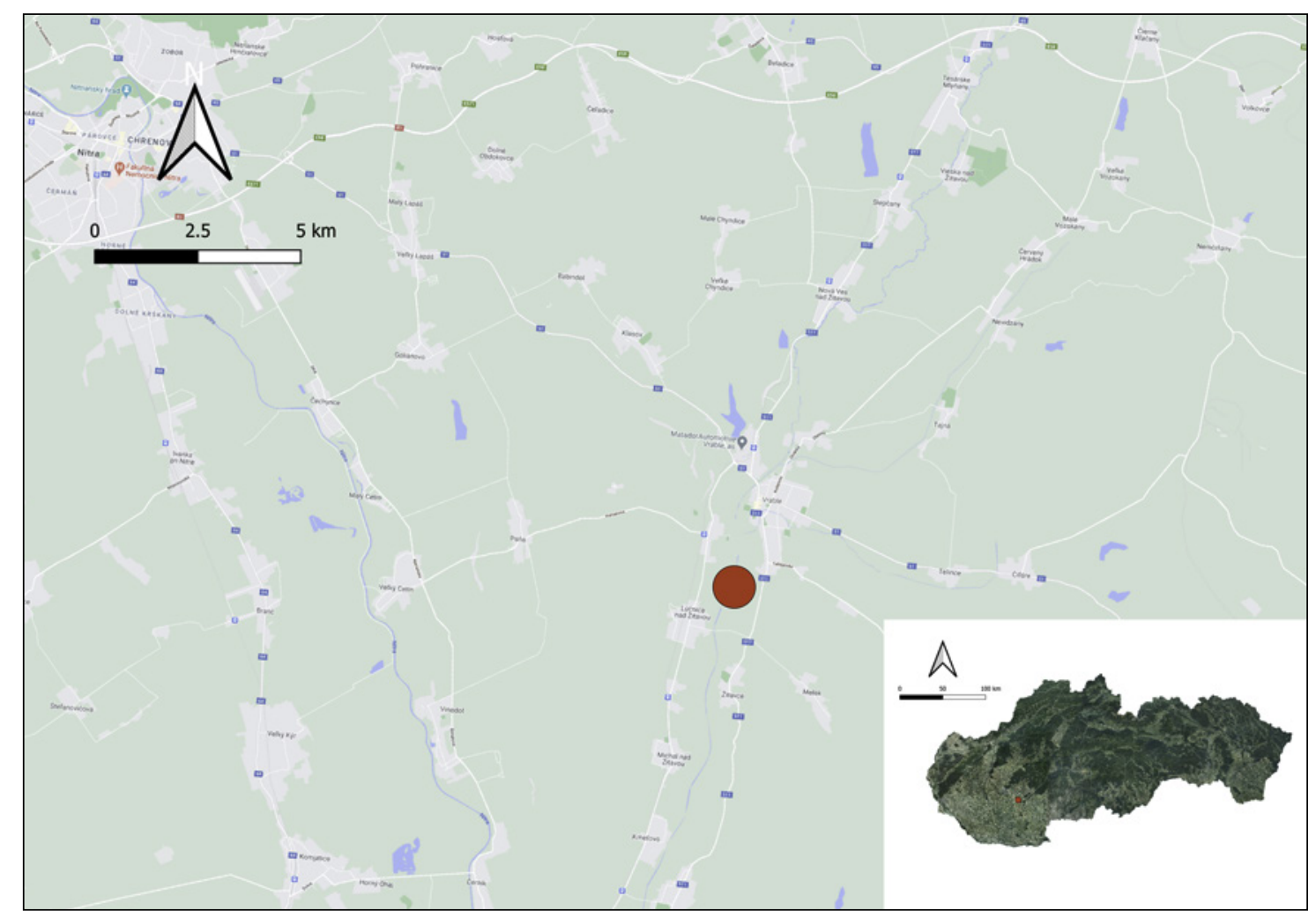

Obr. 1. Poloha lokality Vráble-Fidvár (zdroj dát: ÚGKK SR, Google Maps).

Fig. 1. Site of Vráble-Fidvár (source: ÚGKK SR, Google Maps).

\section{Predmet a ciel' výskumu}

Súbor dát, ktorý bol podrobený priestorovej analýze, je tvorený systematickou vzorkou zo súboru keramických fragmentov. Tie pochádzajú z povrchového zberu, realizovaného Archeologickým ústavom SAV v Nitre, Römisch-Germanische Kommission DAI vo Frankfurte nad Mohanom a Otto-Friedrich-Universität v Bambergu. Pre potreby zberu bola využitá analytická metóda zberu vo štvorcovej sieti (tiež rastrová metóda; obr. 2). Štvorcová siet' je zložená zo sektorov s postupne sa zväčšujúcou plošnou rozlohou $(5 \times 5,10 \times 10,10 \times 20$ a $20 \times 20$ m). Systematická vzorka bola zvolená prostredníctvom dvojfázového vzorkovania, v procese ktorého boli aplikované metódy stratifikovaného a adaptívneho zhlukového vzorkovania. Kombinácia týchto techník zabezpečila (i) rovnomerné, proporčné pokrytie plochy a (ii) odsledovanie najvýraznejších koncentrácií nálezov na skúmanej ploche. Stratifikácia plochy tiež viedla k rozdeleniu štvorcovej siete na štyri menšie priestory - strata $(A, B, C, D)$, ktoré boli zadefinované na základe vel'kosti sektorov (obr. 3) a pokrývali jednotlivé časti lokality (A - centrálna čast', B - rezidenčná čast', C a $\mathrm{D}$ - periféria).

Vzorka sa skladala z 513 sektorov (celkovo 1168, t. j. 44 \% pokrytie) a obsahovala 8918 keramických fragmentov s výslednou hmotnost'ou 172654 gramov. Z hl’adiska pravekého a včasnohistorického osídlenia výrazne dominujú nálezy datované do obdobia staršej doby bronzovej (58,65 \%). Druhou najpočetnejšou kategóriou je eneolitická keramika $(1,14 \%)$, nasledovaná fragmentami zaradenými do obdobia doby rímskej $(0,69 \%)$, doby laténskej $(0,08 \%)$ a neolitu $(0,02 \%)$. Zvyšok keramického materiálu bol tvorený nálezmi zaradenými do skupiny stredovek/novovek $(2,26 \%)$ a nedatovanými fragmentami $(37,15 \%)$.

Ciel’om výskumu bolo zaznamenanie, charakteristika a vizualizácia priestorovej štruktúry osídlenia lokality Fidvár v praveku a včasnohistorickom období na základe dostupnej vzorky. K dosiahnutiu vytýčeného ciel’a boli aplikované inovatívne metódy priestorovej analýzy. Hlavnou myšlienkou predloženého článku je prezentácia techník, pomocou ktorých je možné zachytit' a interpretovat’ výrazné zhluky nálezov. Pomocou nadobudnutých výsledkov je možné vzorku interpolovat' a vizualizovat' základné priestorové trendy prítomné na skúmanej ploche. 


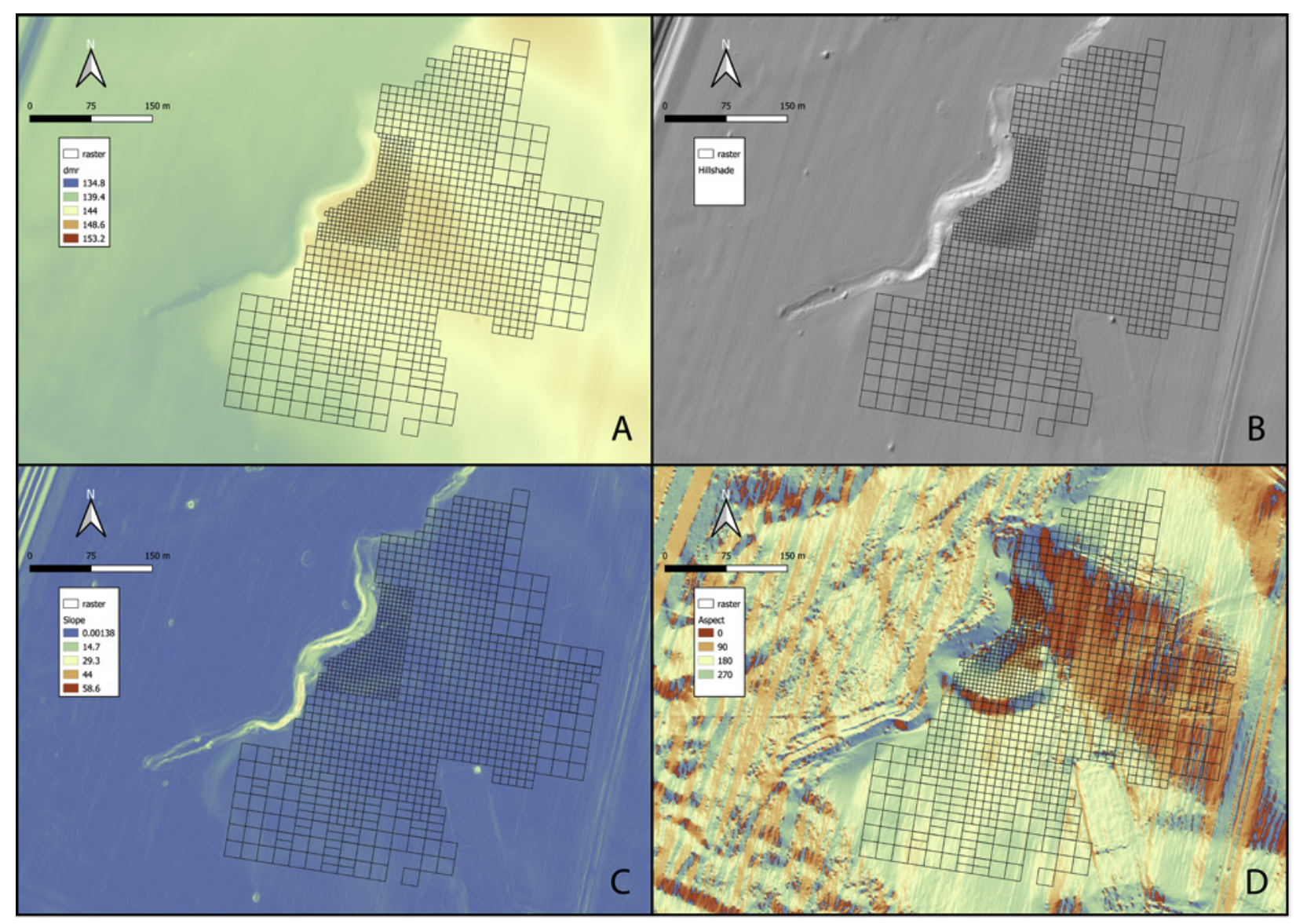

Obr. 2. Analýza digitálneho výškového modelu. A - nadmorská výška (v metroch nad morom) (podl'a Drozd 2020, obr. 1); B - tieňovaný reliéf; C - sklon terénu (v stupňoch); D - orientácia sklonu $\left(0^{\circ}\right.$ - sever; $90^{\circ}$ - východ; $180^{\circ}$ - juh; $270^{\circ}$ - západ) (zdroj dát: ÚGKK SR; výškový systém: Bpv; systém súradníc: S-JTSK Křovák East North, EPSG: 5514; vizualizácia: D. Drozd).

Fig. 2. Digital elevation model analysis. A - elevation (meters above sea level) (after Drozd 2020, fig.1); B - hillshade; C - slope (degrees); D - aspect $\left(0^{\circ}\right.$ - north; $90^{\circ}$ - east; $180^{\circ}$ - south; $270^{\circ}$ - west) (source: ÚGKK SR; elevation system: Bpv; coordinate system: S-JTSK Křovák East North, EPSG: 5514; visualization: D. Drozd).

\section{Použité metódy}

Priestorová analýza bola realizovaná výhradne prostredníctvom počítačového programu R- Studio na báze $\mathrm{R}$ 4.0.3. Ide o globálne využívaný nástroj vhodný pre štatistickú a priestorovú analýzu, ktorý sa postupne etabluje aj v rámci archeológie (napr. Carlson 2017).

Prvá etapa výskumu spočívala $\mathrm{v}$ analýze miery priestorovej autokorelácie $\mathrm{v}$ rámci chronologicko-priestorových dát (neolit, eneolit, doba bronzová, doba laténska, doba rímska). Následne boli výsledky použité pre zostrojenie interpolovaného povrchu s využitím metódy kriging.

\section{1. Priestorová autokorelácia}

V rámci priestorovej analýzy predstavuje priestorová autokorelácia jeden z najdôležitejších konceptov. Jej podstatu zadefinoval v roku 1970, americký geograf Waldo R. Tobler myšlienkou, ktorá je v súčasnosti známa ako „prvý 


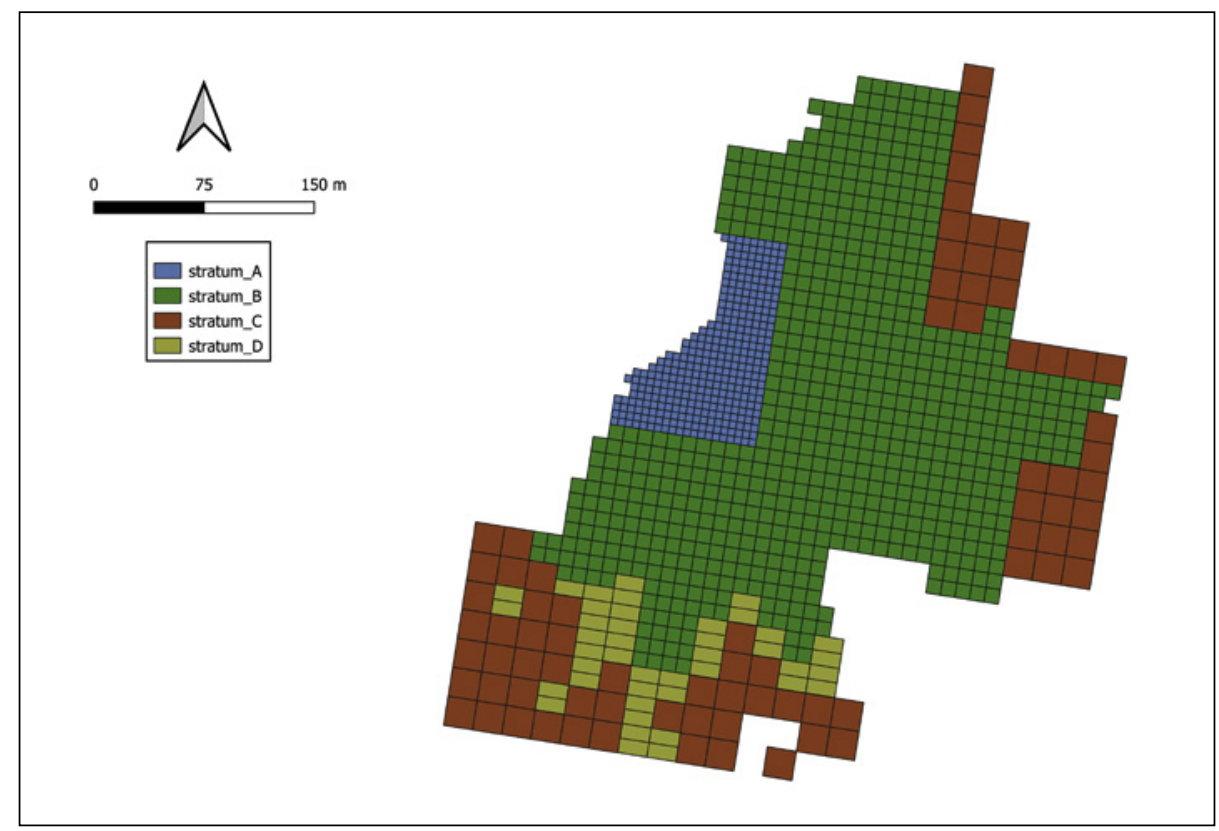

Obr. 3. Stratifikácia plochy (podl'a Drozd 2020, obr. 3A).

Fig. 3. Stratification of the researched area (after Drozd 2020, fig. 3A).

zákon geografie“1 („First Law of Geography“; Tobler 1970). Jej význam spočíva v tvrdení, že z hl’adiska atribútov sú si priestorovo bližšie pozorovania podobnejšie ako tie vzdialenejšie - ako najčastejší príklad býva uvádzaná nadmorská výška.

Základným nástrojom pre vypočítanie miery priestorovej autokorelácie je koeficient Moranovho I. Meranie autokorelácie je testom nulovej hypotézy $\left(\mathrm{H}_{0}\right)$, ktorá predpokladá náhodné usporiadanie pozorovaní v priestore, čo znamená, že hodnota Moranovho I je nulová $(\mathrm{I}=0)$. K zhlukovaniu javov dochádza pokial Moranovo I dosahuje pozitívne hodnoty ( $\mathrm{I}=1$ alebo I > 0), hovoríme o pozitívnej priestorovej autokorelácii. Naopak, negatívna priestorová autokorelácia sa prejavuje v podobe negatívneho koeficientu $(\mathrm{I}=-1$ alebo $\mathrm{I}<0)$ a predstavuje situáciu, $\mathrm{v}$ ktorej sú blízke pozorovania z pohl’adu atribútov, rozdielne (obr. 4).

Pri testovaní nulovej hypotézy vstupuje do procesu aj p-hodnota, ktorá vyjadruje štatistickú signifikanciu výsledných hodnôt. Porovnávaná je s hladinou významnosti $\alpha$, ktorá je stanovená na základe žiadanej spol'ahlivosti. Najčastejšie je využivaná hodnota 95\% $(\alpha=$ $0,05)$, prípadne $99 \%(\alpha=0,01)$. Pokial' je p-hodnota nižšia alebo rovná hladine významnosti, je možné ju označit' za štatisticky signifikantnú a zamietnut' nulovú hypotézu (Triola 2004, 377).

Graficky je možné Moranovo I vyjadrit' prostredníctvom korelogramu alebo tzv. Moranovho diagramu (obr. 5). Ten predstavuje typ grafu, ktorý znázorňuje charakter zachytených zhlukov hodnôt. Skladá sa zo štyroch kvadrantov: pravý horný kvadrant H-H (bigh-high

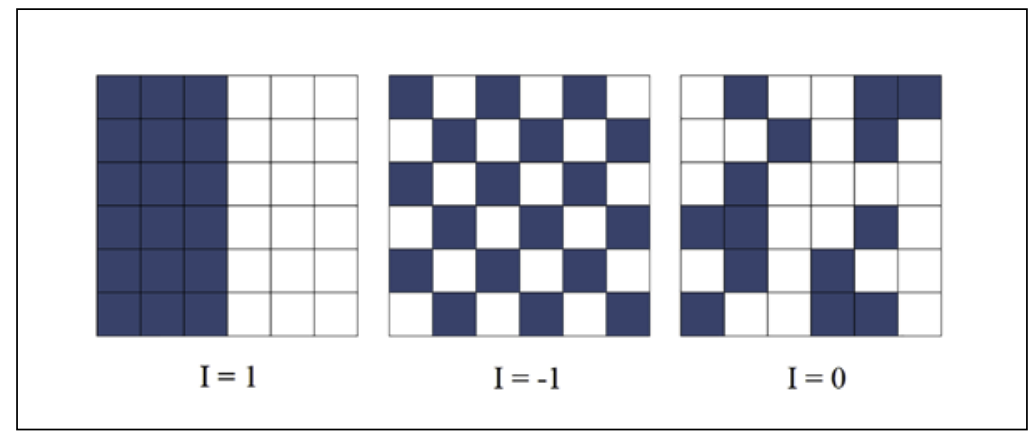

Obr. 4. Princíp priestorovej autokorelácie. $I=1$ - pozitívna priestorová autokorelácia; I = -1 - negatívna priestorová autokorelácia; I = 0 - nulová priestorová autokorelácia (autor: D. Drozd).

Fig. 4. Principle of spatial autocorrelation. $I=1$ - positive spatial autocorrelation; $\mathrm{I}=-1$ - negative spatial autocorrelation; $\mathrm{I}=0$ - spatial autocorrelation is null (author: D. Drozd).

1 „Everything is related to everything else, but near things are more related than distant things.“ (Tobler 1970, 3).

Vol'ný preklad z originálu: „Všetko súvisí so všetkým, ale bližšie javy si sú príbuznejšie ako vzdialenejšie javy.“ 


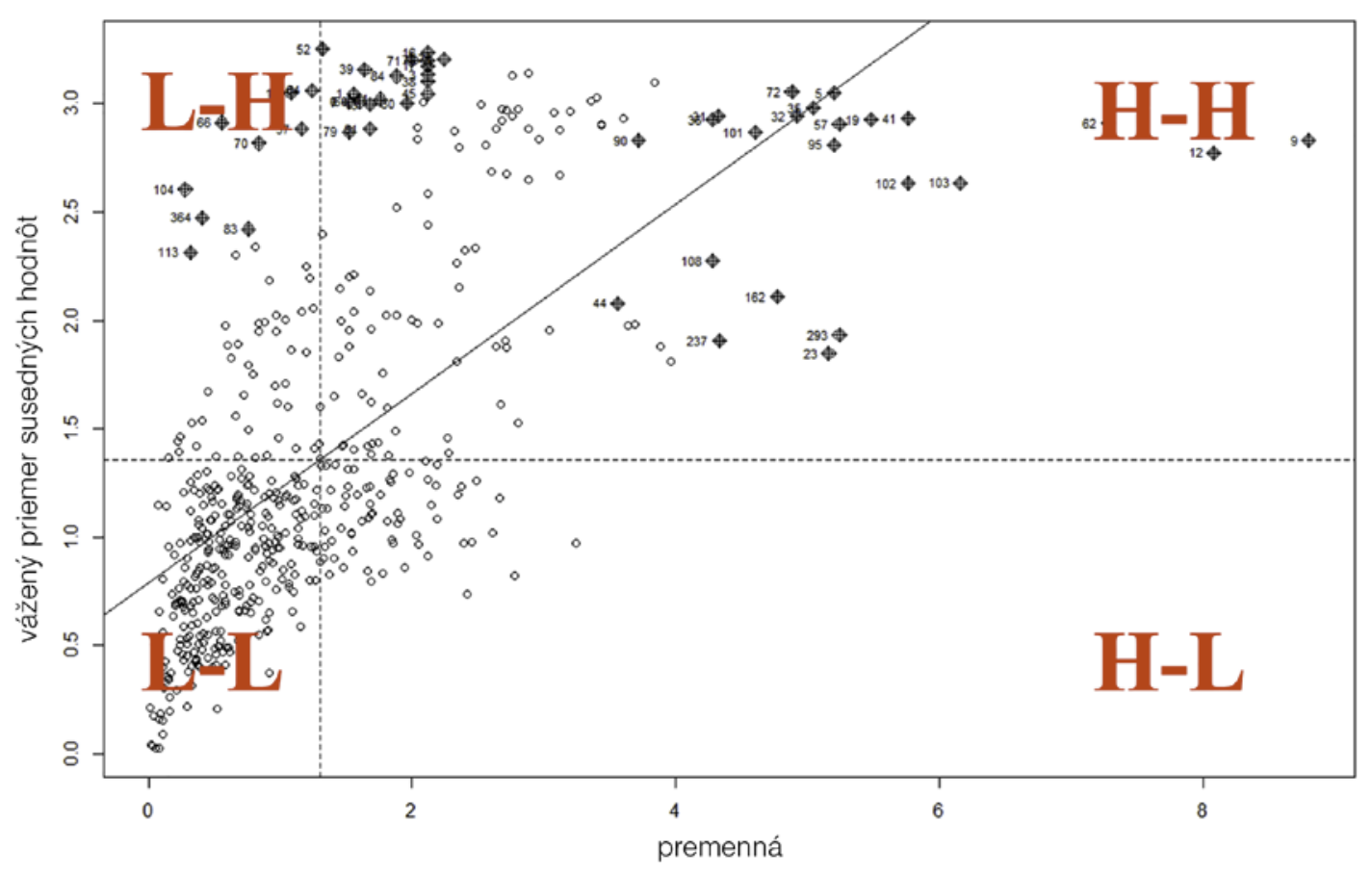

Obr. 5. Moranov diagram (autor: D. Drozd).

Fig. 5. Moran's plot (author: D. Drozd).

- zhlukovanie vysokých hodnôt) a l'avý spodný L-L (low-low - zhlukovanie ní̌kych hodnôt) predstavujú pozitívnu priestorovú autokoreláciu. Naopak, l’avý horný L-H (low-high - nįłke a vysoké hodnoty) a pravý dolný H-L kvadrant (bigh-low - vysoké a nízke hodnoty) reprezentujú negatívnu autokoreláciu. Línia priečne pretínajúca graf vyjadruje mieru pozitívnej alebo negatívnej autokorelácie (Anselin 1990).

Moranovo I je vo svojej podstate tzv. globálnou štatistikou, čo znamená, že jej výsledkom je jedna štatistika pre celý skúmaný priestor a tým pádom je pre jeden parameter získaný jeden odhad (Hodder - Orton 1976; Wheatley Gillings 2002). Využitie globálnej štatistiky však v určitých prípadoch môže narazit’ na určité limity. Ked’že, ako bolo spomenuté, jej výsledkom je iba jedna súhrnná hodnota, nedokáže zachytit’ premenlivost’ koeficientu Moranovho I v sledovanom priestore. Tento koncept sa nazýva stacionarita modelu a predmetom výskumu je variabilita štatistických vzt'ahov a procesov v skúmanom priestore (Crema 2020,155). Hlavná otázka pre výskum variability Moranovho I tak môže byt' sformulovaná nasledovne: „Kde dochádza k najvýraznejšiemu z̧hlukovaniu pozorovanív rámci skúmaného priestoru?".

Pre potreby merania lokálnych trendov bol vyvinutý koeficient lokálneho Moranovho I (LMI), tiež známy pod skratkou LISA (Local Indicator of Spatial Autocorrelation), ktorého autorom je Luc Anselin (Anselin 1995). Koeficient LISA však poskytuje len informáciu o miere zhlukovania a neodpovedá na zásadnú otázku: „Aké hodnoty sa v priestore žhlukujü - vysoké alebo nį́ke?". Z hl’adiska identifikácie zhlukovaných hodnôt bol využitý koeficient lokálneho Getisovho (a Ordovho) G (Getis - Ord 1992), ktorého zobrazenie pomocou bublinového grafu umožňuje lokalizovat' napríklad koncentrácie vysokých a nízkych hodnôt hustoty keramických fragmentov v priestore. ${ }^{2}$

\section{2. Kriging}

Pozitívna priestorová autokorelácia je nevyhnutným predpokladom pre možnost’ interpolácie vzorky pomocou metódy kriging. Ide o geoštatistickú interpolačnú metódu, ktorú vyvinul juhoafrický banský inžinier Danie G. Krige v spolupráci s francúzskym matematikom Georgesom Matheronom (Matheron 1963; 1971). Metóda našla svoje

2 K d’alším aplikáciám lokálnej priestorovej autokorelácie patrí napr. výskum korelácie dátumov na mayských monumentoch (Premo 2004), identifikácia chronologickej neistoty v kultúre Džómon (Crema - Bevan - Lake 2010) alebo analýza obilných źnn na lokalite Hornstaad-Hörnle (Styring a kol. 2016). 
uplatnenie v rôznych vedných odboroch ako geológia, geografia alebo pedológia, no v čoraz väčšej miere sa začína presadzovat' aj na poli archeológie (napr. Zubrow - Harbaugh 1978; Conolly - Lake 2006).

Z dôvodu integrácie geoštatistiky predstavuje kriging o niečo komplikovanejší spôsob interpolácie dát, ktorý však poskytuje presnejšie výsledky ako iné metódy (inverzné váženie vzdialenosti, spline interpolácia) a to najmä vd’aka empiricky získavaným parametrom interpolácie (Conolly 2020, 123).

Proces sleduje vzt’ah medzi rozdielmi vo zvolenej premennej páru vzoriek a ich priestorového umiestnenia (vzdialenost' medzi bodmi). Tento vzt’ah je vyobrazený prostredníctvom grafu, ktorý sa nazýva variogram (zastar. aj semi-variogram). Variogram znázorňuje vzdialenost' medzi vzorkami (os X) v metroch a štatistiku nazývanú (semi) variancia $(\gamma)$ na osi Y. Táto štatistika vyjadruje variabilitu druhej mocniny rozdielov v premennej medzi dvoma vzorkami (bodmi) v rámci definovanej vzdialenosti (Matheron 1963, 1250; Conolly 2020, 124).

Základnou formou variogramu je mračno (variogram cloud), prípadne jeho prehl'adnejšia podoba - tzv. vzorka (variogram sample). Ide o všesmerové (omnidirectional), tzv. izotropické variogramy, ktoré indikujú mieru vplyvu vzdialenosti na priestorovú štruktúru dát.

Opak izotropie predstavuje anizotropia a práve možnost’ výskumu jej miery v dátach je jednou z výhod metódy kriging. Predmetom merania anizotropie je sledovanie priestorového trendu v určitom definovanom smere - orientácia priestorovej autokorelácie na svetové strany. Pre výskum prítomnosti anizotropie v dátach sú najbežnejšie využívané dve techniky, (i) zostrojenie mapy variogramu (variogram map) a (ii) smerové variogramy (directional/anisotropic variograms).

Výskum anizotropie priamo ovplyvňuje možnosti pri zostrojení teoretického modelu variogramu, na základe ktorého je vytvorený súvislý interpolovaný povrch. Pokial' je preukázaná anizotropia, je potrebné tento fakt vziat' do úvahy a teoretický model vyhotovit’ pomocou smerového diagramu. Ak sú dáta izotropické, teoretický model je skonštruovaný prostredníctvom vzorky, ktorá je všesmerová.

Proces tvorby teoretického modelu variogramu spočíva v aproximácii krivky na základe empiricky získaných parametrov, ku ktorým patrí rozsah modelu (range), prah (sill) a počiatočný bod krivky (nugget). Tieto hodnoty sú manuálne zadané do programu R-Studio, ktorý ich s využitím funkcie fit.variogram mierne upraví a prispôsobí krivku danému modelu.

Výsledným výstupom procesu je predikčný model, ktorý zobrazuje priestorovú štruktúru prítomnú v sledovanom súbore dát. Zostrojenie predikčného modelu je možné realizovat' pomocou niekol'kých techník. Medzi základné formy patrí (i) obyčajný, (ii) univerzálny a (iii) jednoduchý kriging (Wackernagel 1995, 74n; Olea 1999, 7n; Conolly 2020, 125). Najpouživanejšou metódou, aplikovanou aj v kontexte tohto článku, je obyčajný kriging, ktorého hlavnou výhodou je široké využitie vo väčšine situácii z dôvodu najmenšieho počtu predpokladov. Jediným podstatným predpokladom je stacionarita variancie dát v skúmanom priestore (Wackernagel 1995, 74n).

\section{Výsledky priestorovej analýzy a diskusia}

Pred začiatkom analýz bola stanovená nulová hypotéza $\left(\mathrm{H}_{0}\right)$ : V priestore vymedzenom štvorcovou siet'ou nie je prítomná priestorová autokorelácia medzi jednotlivými pozorovaniami a teda ich distribúcia je výsledkom náhodného procesu.

Alternatívna hypotéza $\left(\mathrm{H}_{\AA}\right)$ znela: $\mathrm{V}$ priestore vymedzenom štvorcovou siet'ou je prítomná priestorová autokorelácia medzi jednotlivými pozorovaniami a teda dochádza $\mathrm{k}$ ich zhlukovaniu.

Výpočet miery priestorovej autokorelácie závisí na vytvorení susedstva pozorovaní, v rámci ktorého je skúmaný ich vplyv na okolité javy. Susedstvo bolo, v prípade lokality Fidvár, zostrojené na základe vzdialenosti príkazom dnearneigh. Funkcia definuje požadovaný interval vzdialenosti, v ktorej sú vyhl’adávané susedné body pozorovaní. Požiadavkou pri spracovaní dát bolo, aby každý priestorový jav mal minimálne jedného suseda (obr. O), čo vo výsledku predstavovalo interval vzdialenosti od 0 do $29 \mathrm{~m}$. Následne mohla byt' jednotlivým bodom priradená ich váha, t. j. ich vplyv na susedné body (bližšie majú väčší vplyv ako vzdialenejšie).

Výsledné hodnoty koeficientu globálneho Moranovho I boli zhrnuté v tabul'ke, spoločne s príslušnými p-hodnotami pri $99 \%$ spol'ahlivosti (tab. 1) a graficky znázornené pomocou Moranovho diagramu (obr. 7). Z hl’adiska 


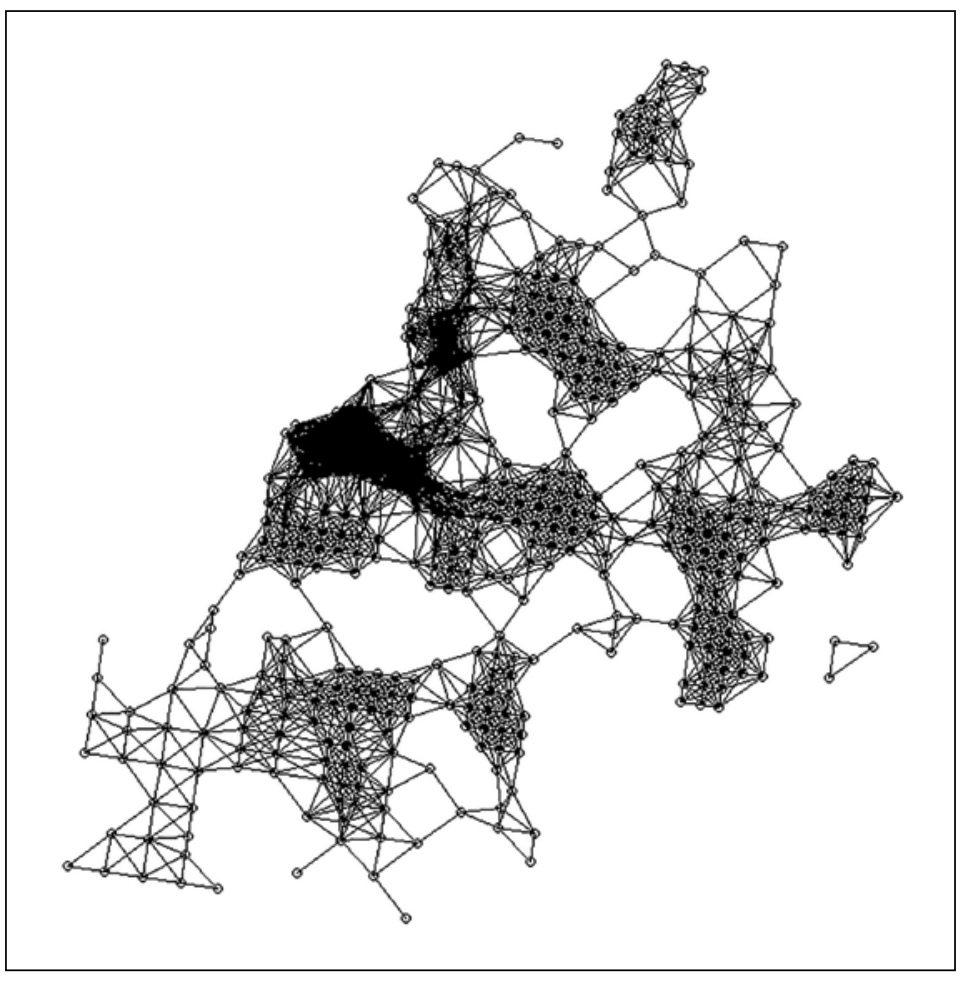

Obr. 6. Siet' susedných bodov určená pre analýzu priestorovej autokorelácie (autor: D. Drozd).

Fig. 6. Network of neighbours used for the analysis of spatial autocorrelation (author: D. Drozd).

\begin{tabular}{|c|c|c|}
\hline data & Moranovo I & p-hodnota \\
\hline NEO & $-0,0015$ & $=0,4828$ \\
\hline ENEO & 0,044 & $=6,08 \mathrm{e}-3$ \\
\hline SDB & 0,43 & $<2,2 \mathrm{e}-16$ \\
\hline LTN & $-0,01$ & $=0,69$ \\
\hline RIM & 0,006 & $=0.3283$ \\
\hline
\end{tabular}

Tab. 1. Výsledky analýzy globálnej priestorovej autokorelácie; $\mathrm{NEO}$ - neolit; ENEO - eneolit; SDB - staršia doba bronzová; LTN - doba laténska; RIM - doba rímska

Tab. 1. Results of the global spatial autocorrelation analysis; NEO - Neolithic; ENEO - Eneolithic; SDB - Early Bronze Age; LTN - La Tène period; RIM - Roman period chronologicko-priestorových dát je možné zamietnut' nulovú hypotézu iba pri nálezoch zo staršej doby bronzovej. Pri ostatných zachytených obdobiach sa hodnota Moranovho I pohybuje okolo nuly, pričom p-hodnota je väčšia ako hladina významnosti $(p>\alpha)-$ tieto javy sú výsledkom náhodného procesu a nulová hypotéza nemôže byt' zamietnutá.

Zaujímavá situácia nastala pri nálezoch datovaných do obdobia eneolitu. Napriek nulovej priestorovej autokorelácii $(0,044)$, bola získaná štatisticky signifikantná p-hodnota $(\mathrm{p}=0,006)$, ktorá umožňuje zamietnut' nulovú hypotézu. Tento výsledok môže indikovat' prítomnost' lokálnej pozitívnej autokorelácie, ktorú globálne Moranovo I nezachytilo.

Detailnejší pohlad na chronologicko-priestorové vzorce reprezentujúce jednotlivé obdobia umožňuje získat' informácie o pravekej a včasnohistorickej štruktúre osídlenia lokality. Dominantné postavenie $\mathrm{v}$ rámci všetkých nálezov majú keramické fragmenty patriace do staršej doby bronzovej. Lokálna analýza prostredníctvom Moranovho I a Getisovho G identifikovala vo vymedzenom priestore najvýraznejšie zhluky keramických fragmentov $\mathrm{v}$ centrálnej časti sídliska (obr. 8). Nižšie, no stále signifikantné hodnoty, vytvárajúce menšie uzatvorené zhluky, sú prítomné v rôznych častiach lokality.

Na lokálnej úrovni sa výraznejšie v centrálnej časti sídliska prejavujú nálezy datované do obdobia eneolitu. Vytvárajú tu menšie, neucelené koncentrácie, pričom ich ojedinelá prítomnost' je evidovaná na celej ploche. Tá je však pravdepodobne výsledkom náhodného procesu. Zaznamenatel'ný je aj mierne zvýšený počet nálezov z doby rímskej v priestore periférie sídliska, najmä na jeho južnom a juhozápadnom okraji. Hodnota lokálneho Moranovho I je však pomerne nízka $\left(I_{R I M}=1,232\right.$, porov. s nálezmi z eneolitu $\left.I_{E N}=4,046\right)$ a ich distribúciu nie je možné označit’ za zhlukovanie v pravom slova zmysle.

Ostatné zachytené obdobia vykazujú nulovú až negatívnu lokálnu priestorovú autokoreláciu, čo znamená, že $\mathrm{v}$ rámci celkového počtu keramických fragmentov je ich distribúcia náhodná (tab. 2).

Analýza miery pozitívnej autokorelácie poukázala na možnost’ vytvorenia predikčného modelu len na príklade nálezov zo staršej doby bronzovej a eneolitu, ktoré jediné vykazovali pozitívne hodnoty globálneho a/alebo lokálneho Moranovho I. Pokus o interpoláciu bol realizovaný aj na nálezoch z doby rímskej. Počas procesu sa však preukázali nízke hodnoty globálnej a lokálnej autokorelácie a predikčný model nebolo možné zostrojit’. V záverečnej interpretácii je tak možné vychádzat’ len z analýzy lokálnej priestorovej autokorelácie nálezov z doby rímskej. 

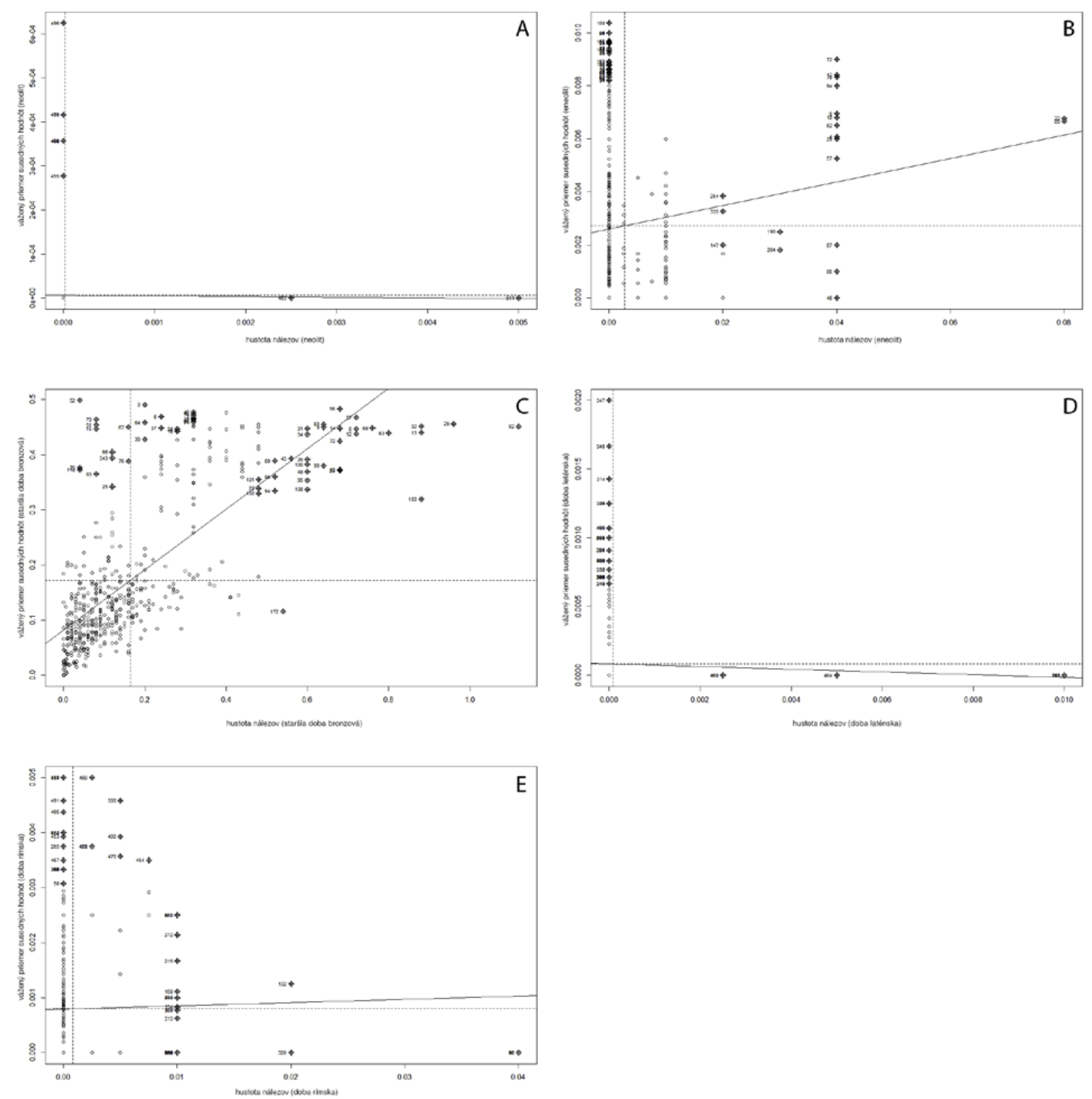

Obr. 7. Grafické zobrazenie globálnej priestorovej autokorelácie prostredníctvom Moranovho diagramu. A - neolit; B - eneolit; C - staršia doba bronzová; D - doba laténska; E - doba rímska (autor: D. Drozd).

Fig. 7. Graphic representation of global spatial autocorrelation through Moran's plot. A - Neolithic; B - Eneolithic; C - Early Bronze Age; D - La Tène period; E - Roman period (author: D. Drozd).

Pred začiatkom interpolácie vzorky bolo potrebné sa vysporiadat's pozitívnym skreslením dát, ked’že metóda kriging je citlivá na vychýlenú distribúciu (Bevan - Conolly 2009). Normalizácia prebehla pomocou tzv. Box-Coxovej transformácie.

Anizotropia dát bola sledovaná prostredníctvom mapy variogramu, ktorá v ani jednom prípade nepreukázala vychýlenie distribúcie v definovaných smeroch $\left(0^{\circ}\right.$ - sever/juh; $45^{\circ}$ - severovýchod/juhozápad; $90^{\circ}$ - západ/východ a $135^{\circ}$ - severozápad/juhovýchod). Distribúcia dát tak mohla byt' označená ako izotropická (obr. 9).

Z tohto dôvodu mohol byt' teoretický model variogramu (obr. 10) zostrojený na základe všesmerovej vzorky, prostredníctvom funkcie fit.variogram, ktorá umožňuje automatickú konštrukciu krivky pomocou empiricky získaných parametrov, (i) rozsahu, (ii) prahu a (iii) počiatočného bodu. Výsledkom namodelovanej krivky bol súvislý interpolo- 

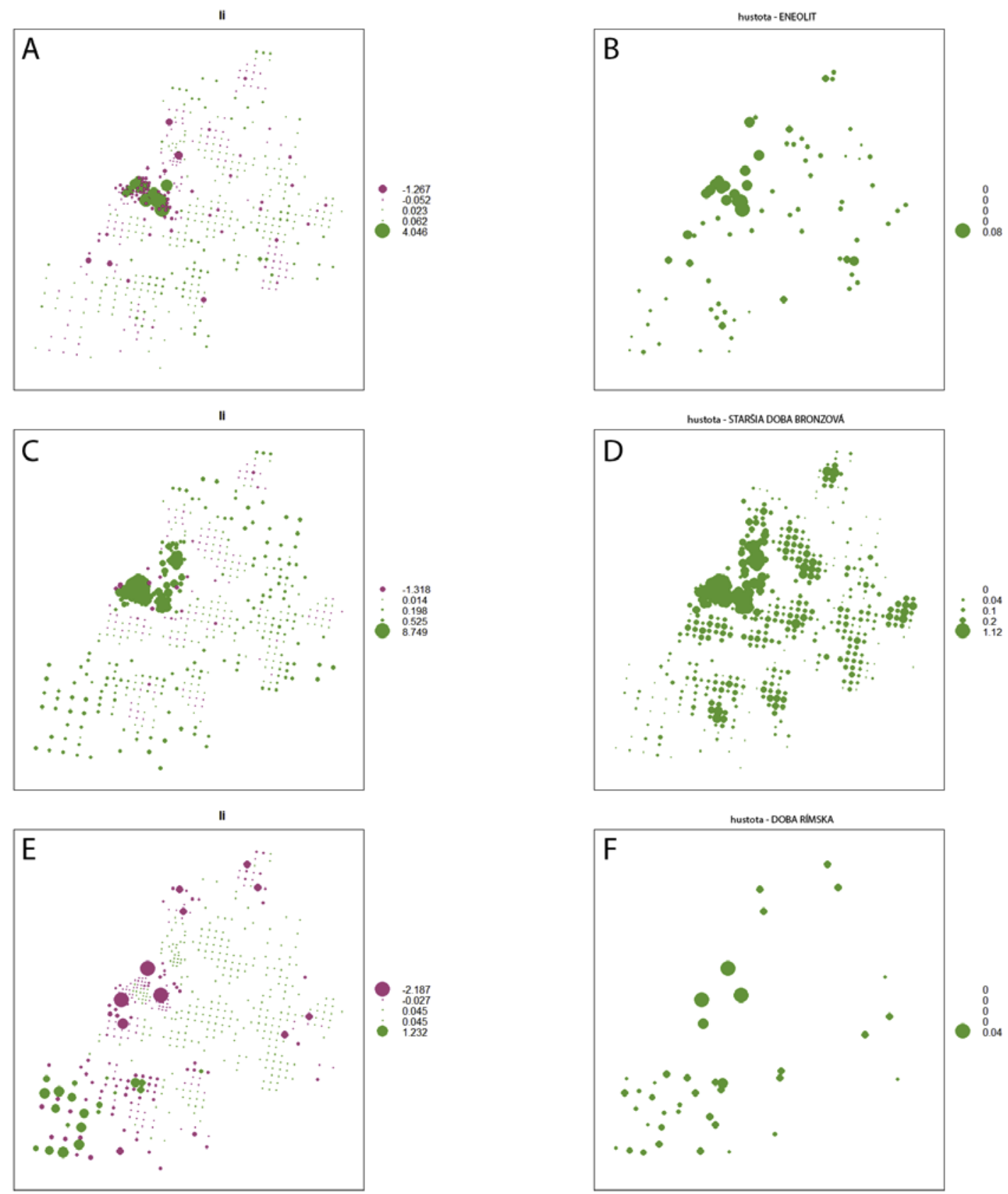

Obr. 8. Grafické zobrazenie lokálnej analýzy dát vykazujúcich pozitívnu priestorovú autokoreláciu. A - eneolit - LMI; B - eneolit - Getisovo G; C - staršia doba bronzová - LMI; D - staršia doba bronzová - Getisovo G; E - doba rímska - LMI; F - doba rímska - Getisovo G (autor: D. Drozd).

Fig. 8. Graphic representation of local data analysis exhibiting positive spatial autocorrelation. A - Eneolithic - LMI; B - Eneolithic - Getis' G; C - Early Bronze Age - LMI; D - Early Bronze Age - Getis' G; E - Roman period - LMI; F - Roman period - Getis’ G (author: D. Drozd).

vaný povrch - predikčný model, vytvorený prostredníctvom metódy obyčajného krigingu. Ten umožnil vizualizáciu priestorovej štruktúry lokality Fidvár z hl’adiska chronologicko-priestorových vzorcov, ktoré vykazovali dostatočnú mieru pozitívnej autokorelácie (obr.11).

Pri všeobecnom pohl’ade na výsledky priestorovej analýzy sa v predikčnom modeli, postavenom na nálezoch zo staršej doby bronzovej, najvýraznejšie prejavuje štruktúra reprezentovaná priestorovo ohraničenými koncentráciami, 

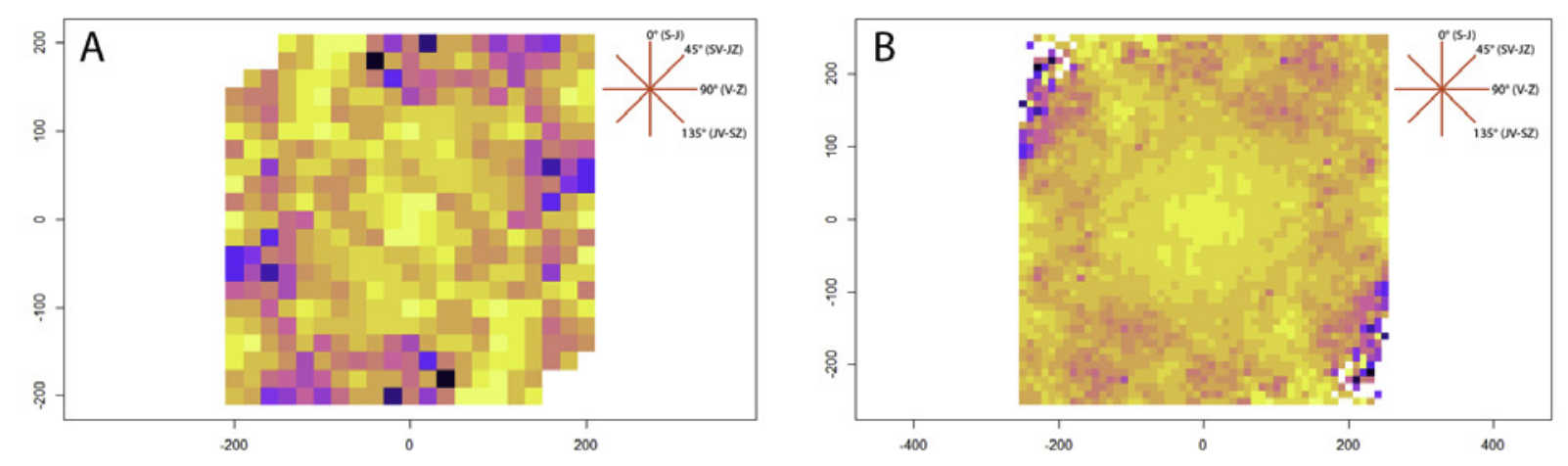

Obr. 9. Mapy variogramu poukazujúce na izotropiu dát. A - eneolit; B - staršia doba bronzová (autor: D. Drozd). Fig. 9. Variogram maps showing the isotropy of data. A - Eneolithic; B - Early Bronze Age (author: D. Drozd).
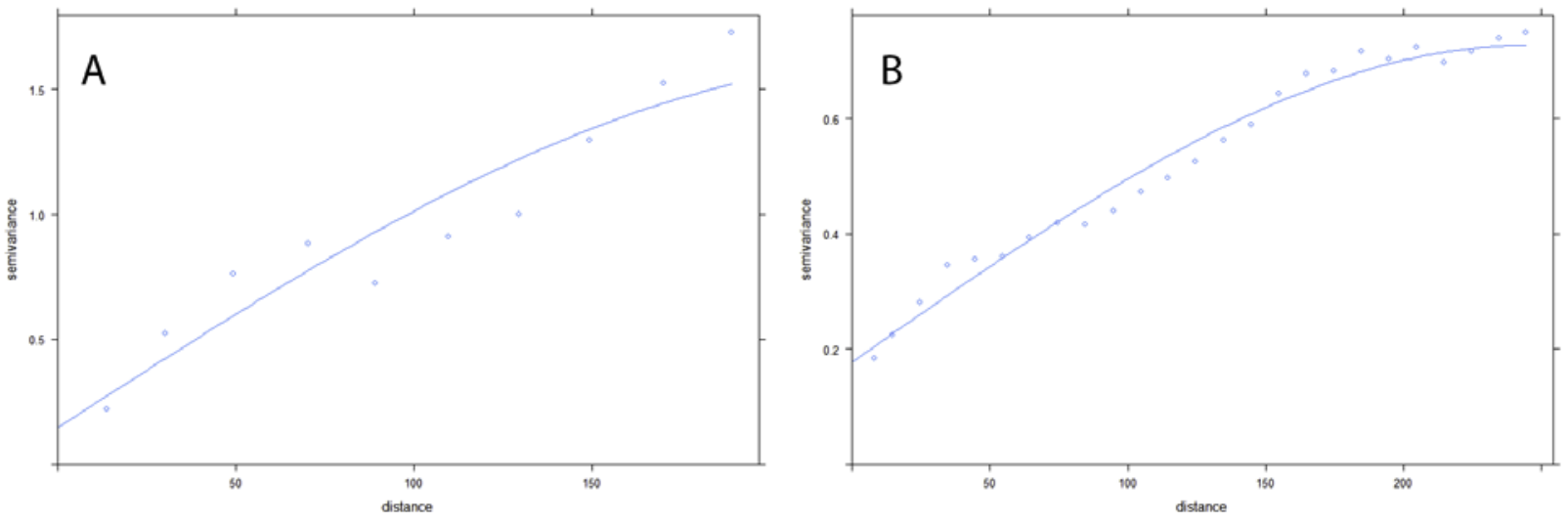

Obr. 10. Teoretický model variogramu. A - eneolit; B - staršia doba bronzová (autor: D. Drozd). Fig. 10. Theoretical variogram model. A - Eneolithic; B - Early Bronze Age (author: D. Drozd).

A

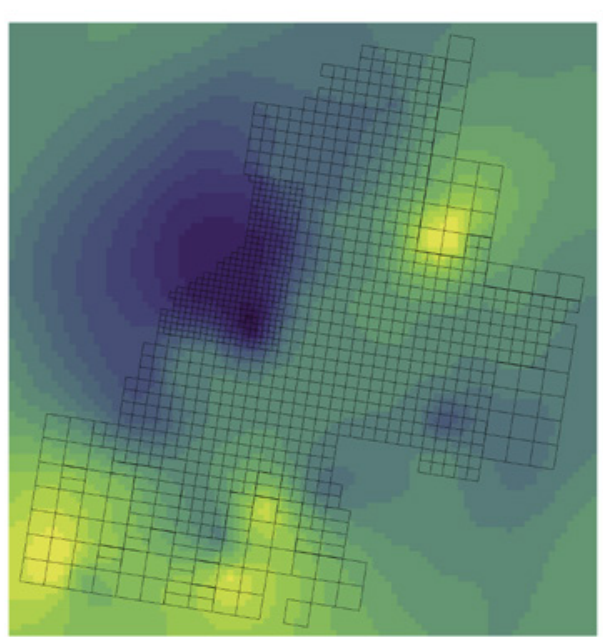

B

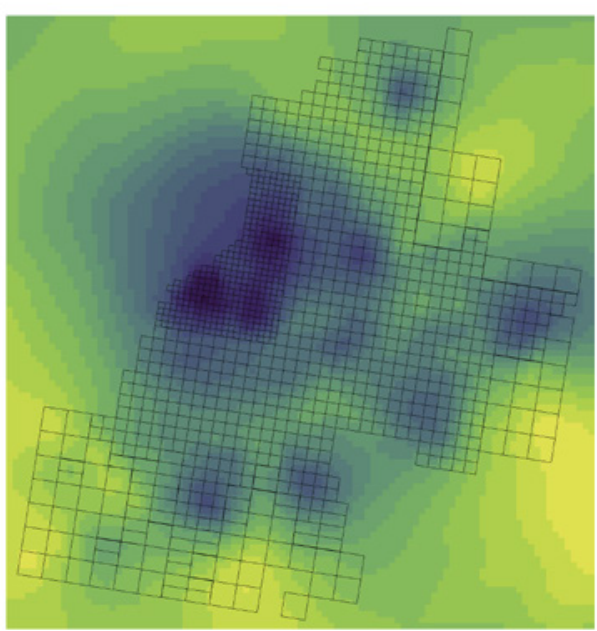

Obr. 11. Predikčný model - kriging. A - eneolit; B - staršia doba bronzová (autor: D. Drozd).

Fig. 11. Prediction surface model - kriging. A - Eneolithic; B - Early Bronze Age (author: D. Drozd). 


\begin{tabular}{|c|c|c|c|c|c|c|}
\hline data & min & 1Q & priemer & median & 3Q & max \\
\hline NEO & $-1,200704$ & 0,003521 & $-0,001486$ & 0,003521 & 0,003521 & 0,003521 \\
\hline ENEO & $-1,26731$ & $-0,05234$ & 0,04437 & 0,02260 & 0,06220 & 4,04594 \\
\hline SDB & $-1,31767$ & 0,01404 & 0,54874 & 0,19794 & 0,52480 & 8,74874 \\
\hline LTN & $-1,186913$ & 0,009327 & $-0,010055$ & 0,009327 & 0,009327 & 0,009327 \\
\hline RIM & $-2,18750$ & $-0,02660$ & 0,00594 & 0,04543 & 0,04543 & 1,23192 \\
\hline
\end{tabular}

Tab. 2. Výsledky analýzy lokálnej priestorovej autokorelácie; min - minimálna hodnota; $1 \mathrm{Q}$ - prvý kvartil; 3Q - tretí kvartil; max - maximálna hodnota; NEO - neolit; ENEO - eneolit; SDB - staršia doba bronzová; LTN - doba laténska; RIM - doba rímska.

Tab. 2. Results of the local spatial autocorrelation analysis; min - minimal value; $1 \mathrm{Q}$ - first quartile; $3 \mathrm{Q}$ - third quartile; max - maximal value; NEO - Neolithic; ENEO - Eneolithic; SDB - Early Bronze Age; LTN - La Tène period; RIM - Roman period.

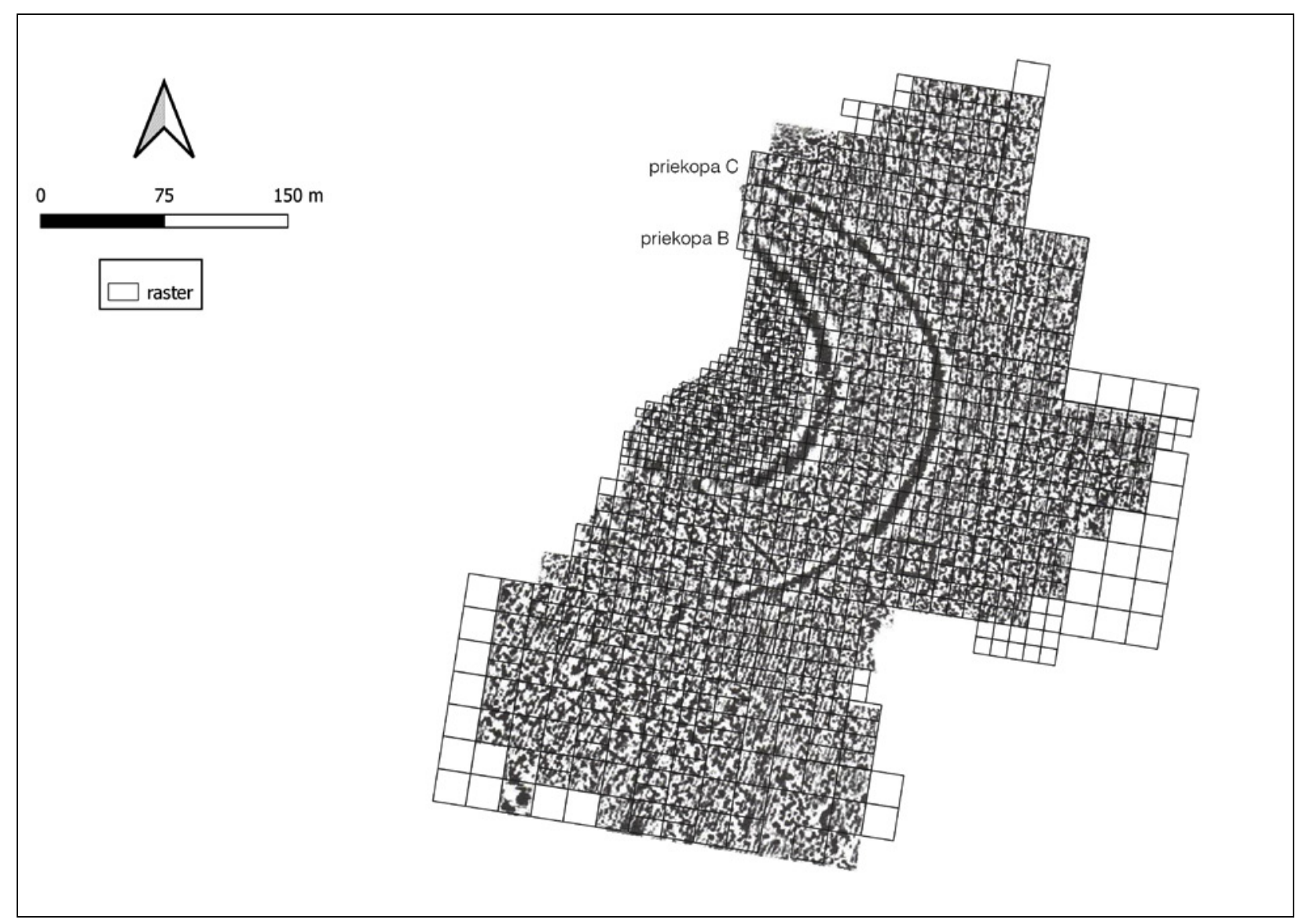

Obr. 12. Plán geomagnetického merania (upravené podl'a Falkenstein et al. 2008, obr. 3).

Fig. 12. Plan of geomagnetics (after Falkenstein et al. 2008, fig. 3).

ktoré sú viditel'ne usporiadané v tvare kruhu. Radiálny vzorec bol zachytený v priestore medzi priekopami B a C, de kopíruje ich priebeh, taktiež na okraji strata $\mathrm{B}$, lemujúc perifériu sídliska. Na periférii sú koncentrácie od seba vo väčšej miere separované, no prítomný radiálny charakter je stále viditel'ný.

O vytváraní rôzne vel’kých a priestorovo ohraničených zhlukov v smere od akropoly sa zmieňuje aj skoršia odborná literatúra, (v ktorej však chýba poznámka o radiálnom charaktere štruktúry) v súvislosti s predbežným vyhodnotením výsledkov povrchového zberu (Bátora et al. 2008; Falkenstein et al. 2008). 

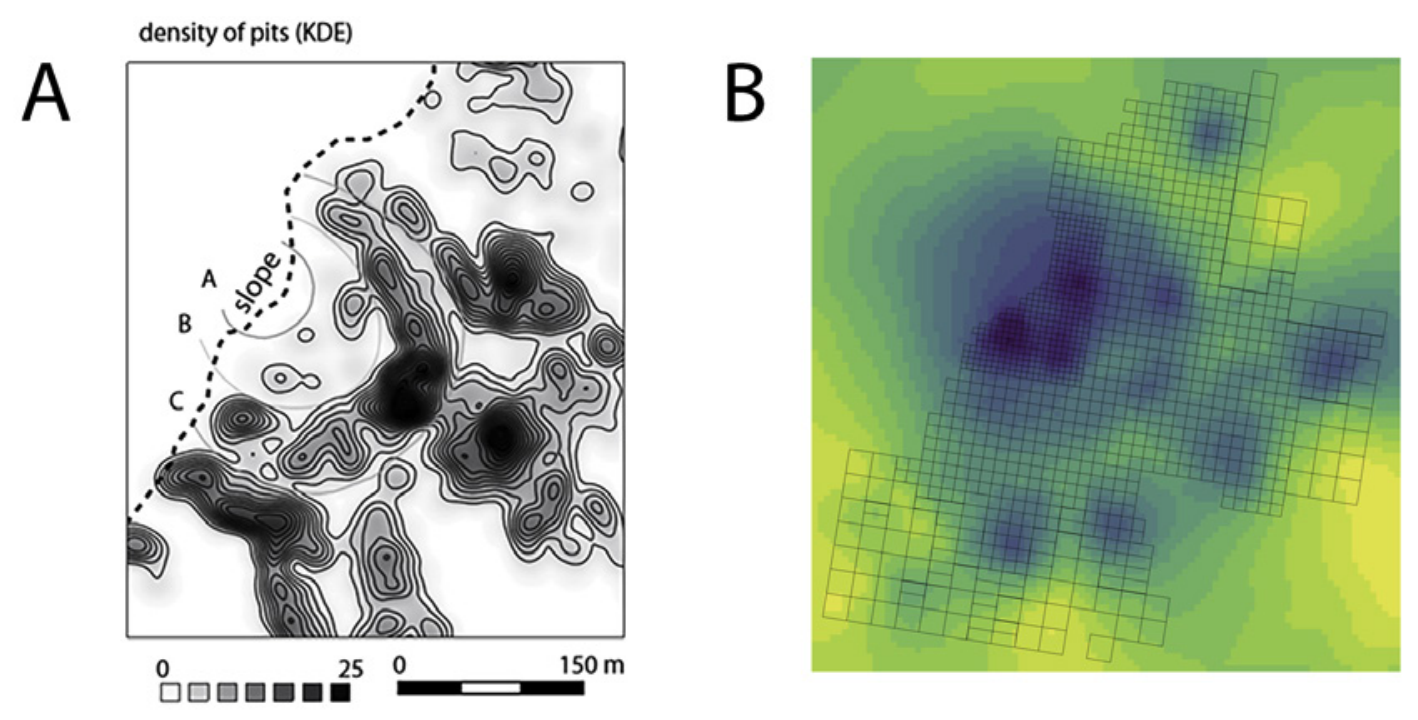

Obr. 13. Porovnanie (A) hustoty zásobných jám na lokalite a (B) predikčného modelu zobrazujúceho koncentrácie nálezov (A - Rassmann et al. 2017, obr. 6; B - autor: D. Drozd).

Fig. 13. Comparison of (A) density of pits at the site and (B) prediction surface model (A - Rassmann et al. 2017, fig. 6; B - author: D. Drozd).

Pri interpretácii zhlukov keramických fragmentov predstavuje dôležitú otázku miera ich korelácie s prítomnými archeologickými objektmi, ktoré je možné evidovat' na mape geomagnetických meraní, ${ }^{3}$ prípadne boli potvrdené exkavačnou činnost'ou v určitých častiach lokality.

Geomagnetický plán (obr. 12), okrem priekop a pôdorysov obydlí, indikuje prítomnost' početných kruhových anomálií, ktoré boli na základe odkryvu interpretované ako zásobné jamy (Bátora et al. 2012, 120). Podl’a plánu distribúcie zásobných, neskôr odpadových, jám v priestore sídliska sú najväčšie zhluky evidované medzi priekopou B a $\mathrm{C}$ a na periférii sídliska (obr.13). Tieto zhluky korelujú so zachytenými koncentráciami keramických fragmentov na základe vzorky, ale taktiež aj so skoršími poznatkami (Rassmann et al. 2017, 85) o distribúcii dát na lokalite.

Najvýraznejšie oncentrácie keramických nálezov boli v procese priestorovej analýzy preukázané v centrálnej časti sídliska. Táto plocha, v rámci štvorcovej siete reprezentovaná stratom A, predstavuje z hladiska hustoty nálezov a miery zhlukovania najintenzívnejšie osídlenú čast’ lokality. Toto tvrdenie je možné podporit’ vývojom osídlenia na lokalite (obr. 14).

Prvé súvislejšie osídlenie sa spája práve s centrálnym priestorom sídliska a prítomnost’ou kultúry Kosihy-Čaka/ Makó. V období staršej doby bronzovej tu bolo založené osídlenie s celkovou rozlohou okolo 0,3 ha, ktoré sa postupne rozšírilo až do svojej vrcholnej podoby $(11 \mathrm{ha})$. Počas poslednej fázy, obdobia mad’arovskej kultúry sa plocha výrazne zmenšila na približne desatinu svojej pôvodnej vel'kosti - 1 ha (Bátora et al. 2012, 125). Centrálna čast' sídliska bola intenzívne využívaná od počiatkov až po zánik osídlenia na lokalite Fidvár. Napriek silnejšiemu vplyvu erózie, vysoké hodnoty hustoty nálezov je možné stotožnit' práve s pretrvávajúcou sídliskovou aktivitou.

Okrem nálezov z obdobia staršej doby bronzovej bolo možné interpolovat’ aj súbor dát patriaci do obdobia eneolitu. Lokálny koeficient Moranovho I zachytil menšie, neorganizované zhluky v priestore akropoly s hodnotou 4,046. Pri interpretácii, je možné vyslovit' predpoklad súvisu tohto materiálu s prítomnost’ou eneolitického sídliska kultúry Kosihy-Čaka/Makó, ktoré sa nachádzalo v tejto časti plochy. Na druhej strane, už spomínaná erózna činnost', ktorá bola dôsledkom strmého sklonu terénu na západnom okraji lokality, znižuje reprezentatívnost' týchto záverov a ich výpovedná hodnota je diskutabilná.

Včasnohistorické osídlenie je doložené nálezmi z obdobia doby rímskej. Ked'že nebolo možné vzorku interpolovat', pre potreby interpretácie je možné využit' len výsledky lokálnej priestorovej autokorelácie. K výraznejšiemu nárastu výskytu týchto nálezov dochádza v južnej a juhozápadnej časti plochy v priestore strat $\mathrm{C}$ a $\mathrm{D}$ (periféria). Ojedinelé nálezy je možné identifikovat' aj v rámci strat $\mathrm{A}$ a $\mathrm{B}$, ktoré sú pravdepodobne výsledkom náhodného procesu.

3 Realizátorom geomagnetických meraní boli Geographisches Institut v Heidelbergu a Otto-Friedrich-Universität v Bambergu. 


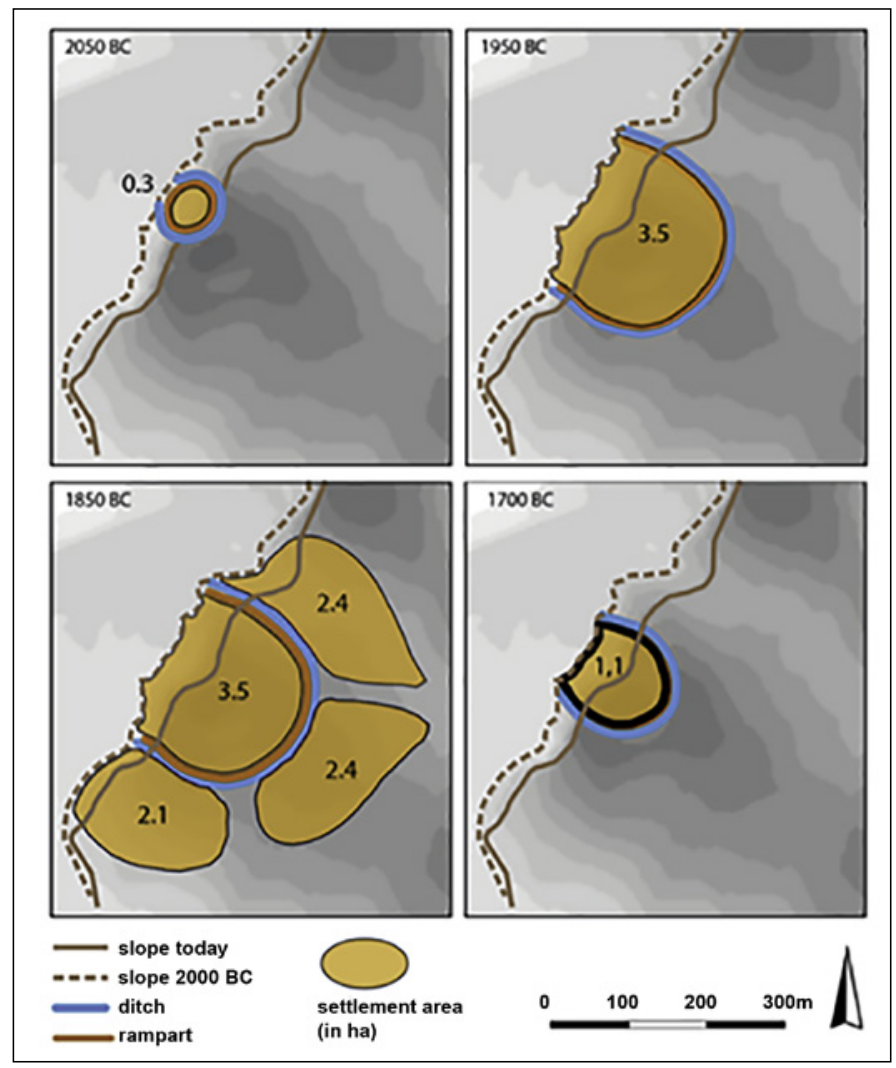

Obr. 14. Vývoj osídlenia lokality Fidvár (Rassmann et al. 2017, obr. 2).

Fig. 14. Development of the settlement at the site of Vráble-Fidvár (Rassmann et al. 2017, fig. 2).

Keramické fragmenty z doby rímskej nevytvárajú priestorové zhluky, čo dosvedčili výsledky priestorovej autokorelácie, ako globálnej $(0,006)$ tak aj lokálnej $(1,232)$.

Lokalizácia týchto nálezov na južnej časti periférie sídliska však nie je náhodná. Ich priestorové umiestnenie súhlasí s už skoršími zisteniami v odbornej literatúre (Bátora et al. 2009), v ktorej sú zhrnuté prvotné závery ohl’adom materiálu z povrchového zberu. Za najmladší materiál boli považované nálezy z doby rímskej, nachádzajúce sa na južnom a juhozápadnom okraji sídliska zo staršej doby bronzovej, ktoré pravdepodobne indikujú prítomnost' germánskeho sídliska zisteného už v roku 1980 pri stavbe plynovodu (Toč́k 1981). Nálezy tak na základe výslednej priestorovej distribúcie, ktorá koreluje s už dostupnými informáciami, môžu byt' interpretované práve v súvislosti s predmetným sídliskom (Bátora et al. 2009; 2015, 28).

Potrebné je sa však zmienit' o prítomnosti krátkodobého rímskeho pochodového tábora, ktorého dvojitá priekopa, na základe geomagnetických meraní, zasahuje do priestoru sídliska zo staršej doby bronzovej. Tento zásah je viditel’ný najmä v južnej časti strata B. Určité ojedinelé keramické fragmenty z doby rímskej by tak bolo možné pripísat' aj prítomnosti tohto tábora nachádzajúceho sa v bezprostrednej blízkosti sídliska.

Dôležitým výsledkom aplikácie metód priestorovej analýzy je tiež poznatok, že iba na základe zvolenej vzorky keramického materiálu s vysokou presnost’ou zachytila priestorové špecifiká sídliskovej štruktúry lokality z hl’adiska pravekého a včasnohistorického osídlenia. Svojimi výstupmi odpovedá na otázku, položenú v odbornom článku (Rassmann et al. 2018), ktorou sa autori pýtajú, či bola v prípade lokality Vráble-Fidvár tak intenzívna a časovo náročná stratégia zberu naozaj potrebná: „The question which arises is, whether such an intensive and time consuming strategy is truly necessary. " 4 (Rassmann et al. 2018, 223). Priestorová analýza priniesla pomerne spol'ahlivé poznatky o štruktúre osídlenia na lokalite Vráble-Fidvár, ktoré korelujú s predchádzajúcimi informáciami.

Je možné vyslovit' tvrdenie, že prezentované metódy predstavujú efektívny spôsob vysporiadania sa s vel'kými množstvami dát prostredníctvom štatistiky a výpočtovej techniky. Napriek tomu, že tieto metódy ešte nie sú v slovenskej archeológii etablované, je dôležité na ich existenciu poukázat'. Z archeológie sa stáva veda, ktorá vo vel'kej 
miere preberá pokročilé metódy vychádzajúce z geológie, geoštatistiky a matematiky, ktoré jej umožňujú objektívne analyzovat' dostupné dáta. Ked’že vývoj týchto metód úzko súvisís s rýchlym rozvojom výpočtovej techniky, ide o jedno z najprogresívnejších odvetví archeológie - jeho poznaním, pochopením a zakomponovaním do výskumu môže slovenská archeológia len získat’.

\section{Záver}

Primárnym ciel’om predloženého článku bolo objasnenie priestorovej štruktúry osídlenia lokality Vráble-Fidvár v pravekom a včasnohistorickom období. Analytický prístup k realizácii povrchového zberu (rastrová metóda) umožnil, pre dosiahnutie vytýčeného ciela, aplikovat' vybrané metódy priestorovej analýzy. Vzorka získaných dát bola podrobená analýze priestorovej autokorelácie, ktorá zachytila výrazné zhlukovanie nálezov zo staršej doby bronzovej a v menšej miere aj z obdobia eneolitu a doby rímskej. Tieto priestorové trendy boli spracované do prehl'adnej grafickej podoby pomocou interpolačnej metódy kriging.

Najmä z hladiska štruktúry osídlenia v staršej dobe bronzovej sa jasne preukázala typická črta - kruhový vzorec súvisiaci s radiálnym usporiadaním obydlí pochádzajúcim z klasickej fázy únětickej kultúry. Najsilnejšie koncentrácie boli identifikované v centrálnej časti sídliska. Vysoké hodnoty hustoty nálezov súvisia s dlhodobým osídlením, t. j. intenzitou osídlenia tohto priestoru. Počiatky prítomnosti kultúr zo staršej doby bronzovej sa viažu práve na centrálnu čast’ sídliska, kedy sa tu nachádzalo sídlisko hatvanskej kultúry. Po postupnom rozmachu a kulminácii sa osídlenie výrazne zmenšuje a v období mad’arovskej kultúry opät' okupuje iba centrálny priestor.

Nálezy z obdobia eneolitu tvoria iba malé nevýrazné koncentrácie v centrálnej časti, kde bolo zaznamenané osídlenie kultúry Kosihy-Čaka/Makó. Ked’že však tento priestor podlahol erózii, nadobudnuté výsledky sú prinajmenšom diskutabilné a ich relevantnost' otázna. Ostatné zachytené eneolitické nálezy sú, podl’a výsledkov priestorovej analýzy, dôsledkom náhodného procesu. Dôležitým poznatkom však ostáva fakt, že v priestore lokality Fidvár bolo eneolitické osídlenie prítomné.

Z hl’adiska včasnohistorického osídlenia sa najvýraznejšie prejavujú nálezy z doby rímskej. Ich zvýšená pravdepodobnost' výskytu bola zaznamenaná v južnej až juhozápadnej časti periférie sídliska. Výskyt nálezov je možné stotožnit' so zachytenou prítomnost’ou germánskeho sídliska (Toč́k 1981; Bátora et al. 2009). Pri interpretácii nálezov z doby rímskej je dôležité pripomenút' existenciu rímskeho pochodového tábora, ktorý zasahoval do priestoru periférie sídliska z juhovýchodnej strany. Je možné vyslovit' domnienku, že určité nálezy by bolo možné spojit' aj s prítomnost'ou tohto tábora.

\section{Bibliografie}

Anselin, L. 1995: Local Indicators of Spatial Association - LISA. Geographical Analysis 27-2, 93-115.

Anselin, L. 1996: The Moran Scatterplot as an ESDA Tool to Assess Local Instability in Spatial Association. In: Fischer, M. - Scholten, H. - Unwin, D. (eds.): Spatial Analytical Perspectives on Gis in Environmental and Socio-Economic Sciences. London, 111-125.

Bátora, J. - Tóth, P. - Rassmann, K. 2015: Centrálne sídlisko zo staršej doby bronzovej vo Vrábloch. In: Bátora, J. Tóth, P. (eds.): Ked’ bronz vystriedal med'. Bratislava - Nitra, 123-138.

Bátora et al. 2008 - Bátora, J. - Eitel, B. - Falkenstein, F. - Rassmann, K. 2008: Fidvár bei Vráble - Eine befestigte Zentralsiedlung der Frühbronzezeit in der Slowakei. In: Müller, J. - Czebreszuk, J. - Kadrow, S. (eds.): Defensive structures from Central Europe to the Aegean in the $3^{\text {rd }}$ and $2^{\text {nd }}$ Millenium BC. Poznan - Bonn, 97-107.

Bátora a kol. 2009 - Bátora, J. - Eitel, B. - Falkenstein, F. - Rassmann, K. 2009: Výsledky povrchovej prospekcie na lokalite Fidvár pri Vrábloch. Archeologické výskumy a nálezy na Slovensku v roku 2007, 25-27. 
Bátora et al. 2012 - Bátora, J. - Behrens, A. - Gresky, J. - Ivanova, M. - Rassmann, K. - Tóth, P. - Winkelmann, K. 2012: The rise and decline of the Early Bronze Age settlement Fidvár near Vráble, Slovakia. In: Kniesel, J. a kol. (eds.): Collapse or Continuity? Environment and Development of Bronze Age Human Landscapes. Bonn, 111-132.

Bátora a kol. 2015 - Bátora J. - Hüssen, C.-M. - Ölvecký, R. - Rajtár, J. - Rassmann, K. - Tóth, P. - Winkelmann, K. 2015: Výsledky archeologického výskumu a prieskumu vo Vrábl’och. Archeologické výskumy a nálezy na Slovensku v roku 2010, 26-30.

Bevan, A. - Conolly, J. 2009: Modelling Spatial Heterogeneity and Nonstationarity in Artefact-Rich Landscapes. Journal of Archaeological Science 36 (4), 956-964.

Carlson, D. L. 2017: Quantitative Methods in Archaeology Using R. Cambridge.

Clarke, D. L. 1977: Spatial Information in Archaeology. In: Clarke, D. L. (ed.): Spatial Archaeology. New York, 1-32.

Conolly, J. 2020: Spatial interpolation. In: Gillings, M. - Hacigüzeller, P. - Lock, G. (eds.): Archaeological Spatial Analysis: A Methodological Guide. Abingdon-New York, 118-134.

Conolly, J. - Lake, M. 2006: Geographical Information Systems in Archaeology. Cambridge.

Crema, E. 2020: Non-stationarity and local spatial analysis. In: Gillings, M. - Hacıüzeller, P. - Lock, G. (eds.): Archaeological Spatial Analysis: A Methodological Guide. Abingdon-New York, 155-168.

Crema, E. R. - Bevan, A. - Lake, M. 2010: A probabilistic framework for assessing spatio-temporal point patterns in the archaeological record. Journal of Archaeological Science 37 (5), 1118-1130.

Droz̨, D. 2020: Analytický povrchový zber na lokalite Vráble - Fidvár. Stav bádania a možnosti spracovania dát. Slovenská archeológia, Supplementum 1, 103-111.

Falkenstein, F. 2008 - Falkenstein, F. - Bátora, J. - Eitel, B. - Rassmann, K. 2008: Fidvár bei Vráble - Archäologische Prospektionen auf einer befestigten Zentralsiedlung der Frühbronzezeit in der Slowakei. Mitteilungen der Berliner Gesellschaft für Anthropologie, Ethnologie und Urgeschichte 29, 38-50.

Getis, A. - Ord, J. K. 1992: The Analysis of Spatial Association by Use of Distance Statistics. Geographical Analysis 24, 189-206.

Goodchild, M. F. 1996: Geographic Information Systems and Spatial Analysis in the Social Sciences. In: Aldenderfer, M. - Maschner, H. D. G. (eds.): Anthropology, Space and Geographic Information Systems. Oxford, 241-250.

Hodder, I. - Orton, C. 1976: Spatial analysis in archaeology. Cambridge.

Matheron, G. 1963: Principles of geostatistics. Economic Geology 58, 1246-1266.

Matheron, G. 1971: The Theory of Regionalized Variables and Its Applications. Les Cahiers du Centre de Morphologie Mathématique de Fontainbleau 5. Paris.

Olea, R. A. 1999: Geostatistics for Engineers and Earth Scientists. New York.

Premo, L. 2004: Local spatial autocorrelation statistics quantify multi-scale patterns in distributional data: An example from the Maya Lowlands. Journal of Archaeological Science 31, 855-866.

Rassmann et al. 2017 - Rassmann, K. - Reiter, S. - Bátora, J. - Müller-Scheessel, N. 2017: The Vráble toolbox: A multidisciplinary investigation of settlement change. In: Heeb, B. S. - Szentmiklosi, A. - Krause, R. - Wemhoff, M. (eds.): The Rise And Fall of Defended Sites In Late Bronze Age And Early Iron Age Of South-East Europe. Berlin, 79-90. 
Rassmann et al. 2018 - Rassmann, K. - Bátora, J. - Müller-Scheessel, N. - Reiter, S. - Ivanova, M. - Bebrens, A. - Radloff, K. - Bắa, M. 2018: Tracing Taphonomic Processes. Multiple Layer Analysis of Ceramic Distribution from Surface Collection and Excavation at the Early Bronze Age Settlement of Vráble-Fidvár. Slovenská archeológia 66, č. 2, 219-234.

Styring et al. 2016 - Styring, A. - Maier, U. - Stephan, E. - Schlichtherle, H. - Bogaard, A. 2016: Cultivation of choice: New insights into farming practices at Neolithic lakeshore sites. Antiquity 90, 95-110.

Tobler, W. R. 1970: A computer movie simulating urban growth in the Detroit region. Economic Geography 46, $234-240$.

Točike, A. 1981: Prieskumy a záchranné výskumy na juhozápadnom Slovensku v roku 1980. Archeologické výskumy a nálezy na Slovensku v roku 1980, 296-310.

Triola, M. F. 2004: Elementary Statistics. London.

Wackernagel, H. 1995: Multivariate Geostatistics. Berlin.

Wheatley, D. - Gillings, M. 2002: Spatial Technology and Archaeology: The Archaeological Applications of GIS. Boca Raton, Florida.

Zubrow, E. B. W. - Harbangh, J. W. 1978: Archaeological prospecting: kriging and simulation. In: Hodder, I. (ed.): Simulation models in archaeology. Cambridge, 18-29.

\section{Summary}

This article presents results obtained from spatial analysis of the surface finds collected during fieldwalking campaign (2007) at the site of Vráble-Fidvár. The population of the finds was systematically sampled, in a manner, that the final sample would be representative of the whole population. The study area was stratified into four smaller strata, which were (i) randomly sampled and then (ii) subjected to adaptive cluster sampling for the identification of clusters. This sample was spatially autocorrelated using both global and local Moran's I and finally interpolated and visualised by geostatistical method of kriging.

Through spatial autocorrelation, several clusters of Early Bronze Age finds were identified. Most notably, a radial pattern exhibited in the residential area and parts of the periphery. Also, strong autocorrelation was identified in the central part of the site. These results could be interpreted in accordance with previous knowledge about the structure of the site. Early Bronze Age Fidvár is known for its specific residential structure - radial organisation of houses. Located clusters could be correlated with clusters of pits and house structures present on the geomagnetic plan. High values of density of finds in the central area was probably the result of intensity of settlement activity. It was in this part where the first small settlement (Hatvan culture - ca. $0.3 \mathrm{ha}$ ) was established. Then, the size of the settlement increased (Únětice culture - ca. 11 ha) significantly. In the final phases of activity (Mad'arovce culture - ca. $1 \mathrm{ha}$ ), the settlement diminished and was once again covering the central part.

As for other spatio-temporal patterns, the eneolithic finds exhibited stronger autocorrelation in the central part, possible outcome of the small Kosihy-Čaka/Makó settlement. Due to erosion, which destroyed a significant part of the central area - these results are, at best, debatable.

Last but not least, a higher amount of Roman period potsherds were located in the south and south-west of the Early Bronze Age settlement. Interpretation was based on the previous information about Germanic settlement by A. Točík in 1981, with which it correlated rather well. In this case, a presence of two Roman military camps (one of them visible in south part of the site), needs to be mentioned as some of the finds may be presumably also assigned to them. 